\title{
Erratum to: Evidence based on studies of the mus309 mutant, deficient in DNA double-strand break repair, that meiotic crossing over in Drosophila melanogaster is a two-phase process
}

Petter Portin

Published online: 21 November 2010

(C) Springer Science+Business Media B.V. 2010

Erratum to: Genetica (2010) 138:1033-1045

DOI 10.1007/s10709-010-9489-1

This article has been retracted because it contains material already published elsewhere by the same author.

The online version of the original article can be found under doi:10.1007/s10709-010-9489-1.

P. Portin $(\bowtie)$

Laboratory of Genetics, Department of Biology,

University of Turku, 20014 Turku, Finland

e-mail: petter.portin@utu.fi 